\title{
RESEARCH
}

Open Access

\section{The impact of chronic co-exposure to different heavy metals on small fibers of peripheral nerves. A study of metal industry workers}

Magdalena Koszewicz ${ }^{1 *}$ D, Katarzyna Markowska ${ }^{1}$, Marta Waliszewska-Prosol ${ }^{1}$, Rafał Poreba ${ }^{2}$, Paweł Gac ${ }^{3}$, Anna Szymanska-Chabowska², Grzegorz Mazur ${ }^{2}$, Malgorzata Wieczorek ${ }^{4}$, Maria Ejma ${ }^{1}$, Krzysztof Slotwinski ${ }^{1}$ and Slawomir Budrewicz ${ }^{1}$

\begin{abstract}
Background: Chronic exposure to heavy metals affects various organs, among them the brain and peripheral nerves. Polyneuropathy is mainly length-dependent with predominantly sensory symptoms. There have been few studies on small fiber neuropathy due to heavy metal intoxication.

Methods: We investigated 41 metal industry workers, mean age $51.3 \pm 10.5$ years, with at least 5 years' professional exposure to heavy metals, and 36 age- and sex-matched healthy controls. We performed neurological examinations, and assessed blood levels of cadmium, lead, and zinc protoporphyrin, urine levels of arsenic, standard, sensory and motor electrophysiological tests in the ulnar and peroneal nerves, sympathetic skin responses from the palm and foot, and quantitative sensation testing from dermatomes C8 and S1.

Discussion: The results of standard conduction tests of all nerves significantly differed between groups. The latency of sympathetic skin responses achieved from the foot was also statistically significantly prolonged in the study group. Significant differences were seen in both C8 and S1 regions for temperature and pain thresholds, and for vibratory threshold only in the $\mathbf{S 1}$ region, while the dispersions of low and high temperatures were important exclusively in the C8 region.

Conclusions: We can conclude that co-exposure to many heavy metals results in explicit impairment of peripheral nerves. The lesion is more pronounced within small fibers and is predominantly connected with greater impairment of temperature-dependent pain thresholds. The evaluation of small fiber function should be considered in the early diagnosis of toxic polyneuropathy or in low-dose exposure to heavy metals.
\end{abstract}

Keywords: Cadmium, Lead, Arsenic, Polyneuropathy, Small fibers

\footnotetext{
*Correspondence: magda.koszewicz@onet.pl

${ }^{1}$ Department of Neurology, Wroclaw Medical University, Borowska 213,

50-556 Wroclaw, Poland

Full list of author information is available at the end of the article
}

(C) The Author(s). 2021 Open Access This article is licensed under a Creative Commons Attribution 4.0 International License, which permits use, sharing, adaptation, distribution and reproduction in any medium or format, as long as you give appropriate credit to the original author(s) and the source, provide a link to the Creative Commons licence, and indicate if changes were made. The images or other third party material in this article are included in the article's Creative Commons licence, unless indicated otherwise in a credit line to the material. If material is not included in the article's Creative Commons licence and your intended use is not permitted by statutory regulation or exceeds the permitted use, you will need to obtain permission directly from the copyright holder. To view a copy of this licence, visit http://creativecommons.org/licenses/by/4.0/ The Creative Commons Public Domain Dedication waiver (http://creativecommons.org/publicdomain/zero/1.0/) applies to the data made available in this article, unless otherwise stated in a credit line to the data. 


\section{Introduction}

Chronic exposure to heavy metals affects various organs, including the brain and peripheral nerves. Heavy metal intoxication is a well-known cause of peripheral neuropathy. The clinical picture of such toxic polyneuropathies usually matches a sensoro-motor pattern with paresthesias, and in some cases weakness of the distal muscles, e.g. length-dependent neuropathy with predominant sensory symptoms [1-4]. Acute onset is rare, but possible [5]. Arsenic polyneuropathy is mainly characterized by axonal damage to sensory nerves [6] and is found in above $95 \%$ of patients. Motor neuropathy with a mainly demyelinating pattern, as an exception among others, is classically attributed to chronic lead intoxication [7-10], but there are literature items indicating the possibility of mild sensory and autonomic fiber dysfunction $[9,11]$, as well as mixed damage to peripheral nerves [12]. Cadmium poisoning is mainly connected with behavioral changes $[13,14]$, and there are few studies on possible polyneuropathy [15]. These three heavy metals are among the most common toxic metals and co-exposure to them in high concentrations occurs mainly in the metal industry. Despite the protection of employees, prolonged occupational exposure to heavy metals may cause toxic symptoms [16-18].

Standard electrophysiological methods allow estimation of conduction parameters in peripheral nerves, and in sensory and motor fibers, but only in those of the largest diameter [1, 19-21]. In toxic polyneuropathies, sensory fibers seem to be more often damaged than motor ones, not so infrequently subclinically, or the impairment applies only to small fibers [22-25]. The additional assessment of small fiber function could be useful in the diagnostics of subclinical toxic polyneuropathy. Quantitative sensation testing (QST) allows evaluation of thermal and vibratory perception. Based on the determination of cold, warm and temperature-induced pain or vibratory thresholds, the function of small A-delta, and C fibers could be assessed together with larger fibers - A-beta. Additionally, the evaluation of autonomic fiber function is commonly used in the examination of small fiber polyneuropathy $[1,26,27]$.

The aim of this study was the electrophysiological evaluation of peripheral nerves with regard to the function of small fibers in workers occupationally co-exposed to arsenic, cadmium, and lead. Attention was paid to the eventual correlations between toxicological and electrophysiological parameters in order to estimate the pattern of electrophysiological changes to peripheral nerves.

\section{Materials and methods}

The Ethics Committee of Wroclaw Medical University in Poland gave its approval for the study. Informed consent for participation in the study was obtained from all volunteers.

We investigated 41 employees of the "Legnica" and "Głogów" Copper Smelters and Refineries (Poland), 40 men and 1 woman, mean age $51.3 \pm 10.5$ years. The average weight in the study group was $85.22 \pm 10.72 \mathrm{~kg}$, and body mass index (BMI) was $27.63 \pm 2.97 \mathrm{~kg} / \mathrm{m}^{2}$ All participants had documented professional exposure to heavy metals for at least 5 years, subject to the use of professional security methods. We excluded all participants with additional diseases and conditions influencing the peripheral nervous system: diabetes mellitus, hormonal, rheumatic, and malignant diseases, vitamin deficiency, addiction to alcohol and drugs, and current professional exposure to chemical substances other than heavy metals and physical burdens. The control group consisted of 36 healthy individuals not professionally or incidentally exposed to heavy metals, age- and sexmatched (35 men and 1 woman, $51.1 \pm 12.7$ years old), with similar body weight $(80.50 \pm 9.12 \mathrm{~kg}, p>0.05)$ and BMI $\left(26.68 \pm 1.81 \mathrm{~kg} / \mathrm{m}^{2}, \mathrm{p}>0.05\right)$.

Standard employment and medical histories with information including lifestyle were collected from all participants. Clinical neurological examination, and biochemical tests were performed. In the toxicological analysis we estimated: blood levels of cadmium (Cd-B), and lead (Pb-B) and urine levels of arsenic (As-U). Zinc protoporphyrin $(\mathrm{ZnPP})$ level was evaluated as a toxic effect marker of $\mathrm{Pb}$. Values of Cd-B higher than $-5 \mu \mathrm{g} / \mathrm{l}, \mathrm{Pb}-\mathrm{B}-500 \mu \mathrm{g} / \mathrm{l}$, $\mathrm{ZnPP}-70 \mu \mathrm{g} / \mathrm{dl}$, and As-U - $35 \mu \mathrm{g} / \mathrm{g}$ creatinine were considered the highest acceptable concentrations. $\mathrm{Pb}-\mathrm{B}$ and $\mathrm{Cd}-\mathrm{B}$ were estimated by use of atomic absorption spectroscopy in a graphite furnace with a Solaar M6 apparatus, Thermo Elemental, UK. For As-U estimation, atomic absorption spectroscopy using the hydride generation method with a VP100 Continuous Flow Vapor System was used. The analysis of $\mathrm{ZnPP}$ concentration in erythrocytes was evaluated using a fast fluorimetric method with a hematofluorimeter, ProtoFluor Helena (USA). All toxicological tests were carried out according to the standards of the Institute of Occupational Medicine in Łódź.

Electrophysiological studies were performed with a Viking Quest version 10.0 device connected with a Thermal Sensory Analyzer II 2001 (TSA II) (Medoc, Israel), Viking Select version 7.1.1c., and a Nicolet Biomedical device with the Multi-Mode Program (MMP Plus) software. All tests were performed at a room temperature of between 21 and $23^{\circ} \mathrm{C}$, skin temperature was equal to or above $32{ }^{\circ} \mathrm{C}$.

In the nerve conduction study (NCS), we evaluated motor and sensory parameters in the ulnar and peroneal nerves (sural nerve for sensory conduction estimation in the lower limb) on the left side. We analyzed distal 
latency (in milliseconds - ms), amplitude (in millivolts $\mathrm{mV}$ for motor potentials, in microvolts $-\mu \mathrm{V}$ for sensory potentials), and conduction velocities (in meters per second $-\mathrm{m} / \mathrm{s}$ ), using standard methods $[19,20]$. The distances between electrodes and points of motor fiber stimulations at the wrist and ankle were standard: 5.5 $\mathrm{cm}$ and $8 \mathrm{~cm}$, respectively. We analyzed motor conduction velocity along the nerves on the forearm (wrist elbow) and on the calf (ankle - fibula). For sensory conduction evaluation, we used the antidromic method. The sensory responses were obtained from the fifth digit for the ulnar nerve, and from the lateral ankle region for the sural nerve. The distances between stimulating and recording electrodes varied from 11 to $13 \mathrm{~cm}$ for both nerves. The duration of the electrical stimulation was $0.2 \mathrm{~ms}$.

Sympathetic skin responses (SSR) for electrical stimuli were assessed from the left hand and foot. Unexpected square electrical impulses of 10 to $30 \mathrm{~mA}$ were used. We stimulated the wrist region on the opposite side. We analyzed the shortest latency, and the amplitude of SSR, but for the statistical analysis used only the latency parameter [19, 27, 28].

QST allowed us to estimate the sensation and pain thresholds for cold and warm temperatures (cold sensation - CS, warm sensation - WS, cold pain - CP, heat pain - HP), and additionally the vibration threshold (vibratory sensation - VS). We also analyzed the temperature differences (dispersion of temperature); that is, the difference between feeling pain and temperature sensation (CS - CP, and HP - WS), which reflects dispersion of the temperature. We applied limit methods in the QST study. The thermode was attached to the skin on the region of the $\mathrm{C} 8$ dermatome (hypothenar region) for the ulnar nerve, and for the S1 dermatome (upperlateral surface of the foot) for the sural nerve. The temperature changed by $1{ }^{\circ} \mathrm{C} / \mathrm{s}$ for temperature threshold, and by $2{ }^{\circ} \mathrm{C} / \mathrm{s}$ for pain threshold estimation. The adaptation temperature was constant and equal to $32^{\circ} \mathrm{C}$. Vibratory stimulation was performed using a special device module. The patients put their little finger (the ulnar nerve) and little toe (the sural nerve) on a vibrating button. The stimulation parameters were: rate - 100 $\mathrm{Hz}$, amplitude range - 0 to $130 \mu \mathrm{m}(\mu)$, and amplitude change rate $-0.3 \mu \mathrm{m}$ per second $(\mu / \mathrm{s})$. The stimulation for all thresholds was stopped when the patient pressed a button. The procedures were repeated 4 times for temperature, 3 times for pain, and 6 times for vibration threshold estimation. The thresholds were calculated as the average values, in ${ }^{\circ} \mathrm{C}$ and $\mu$, respectively $[26,29,30]$.

Statistical analysis was performed with STATISTICA 12.0 software (Statsoft Polska Sp. z o.o., Krakow, Poland). The statistical analysis included: the number of cases $(\mathrm{N})$, and mean values $(\mathrm{X})$ with standard deviations
(SD) of the continuous parameters. For data with a normal distribution and homogeneity of variance the student t-test was used; for those with a normal distribution but without homogeneity of variance, the Cochran-Cox test was employed. The Mann-Whitney U was used for data without a normal distribution, and this concerned most of the calculated parameters. The normality of distribution was assessed using the ShapiroWilk test. The significant $p$-value was $\leq 0.05$. Based on Guilford's interpretation of the magnitude of significant correlations.

\section{Results}

All volunteers met the inclusion / exclusion criteria. All underwent neurological examinations. Only 8 patients (19.5\%) had the clinical symptoms of polyneuropathy, i.e. impaired sensation and / or diminished or absent deep reflexes in the distal localization (both were seen in 3 persons). In all of these, abnormalities were found only in lower limbs.

Basic biochemical analyses were within normal limits. The average level of As- $U$ was $15.60 \pm 15.58 \mu \mathrm{g} / \mathrm{g}$ creatinine, and in 4 persons the level was above $35 \mu \mathrm{g} / \mathrm{g}$ creatinine. Cd-B mean level was $1.19 \pm 1.40 \mu \mathrm{g} / \mathrm{l}$, Pb-B $181.85 \pm 139.88 \mu \mathrm{g} / \mathrm{l}$, and for both metals only in $1 \mathrm{vol}-$ unteer did the level exceed the higher acceptable concentration. This patient with a high $\mathrm{Cd}-\mathrm{B}$ value $(7.17 \mu \mathrm{g} /$ 1) also had a high level of As-U ( $88 \mu \mathrm{g} / \mathrm{g}$ creatinine). The average concentration of $\mathrm{ZnPP}$ was $18.35 \pm 22.00 \mu \mathrm{g} / \mathrm{dl}$, while in 2 persons it was higher than $70 \mu \mathrm{g} / \mathrm{dl}$.

Standard motor and sensory conduction tests of the peripheral nerves differed statistically significantly in terms of nearly all parameters in the peroneal nerve, while in the ulnar nerve the differences were less obvious. All values are shown in Tables 1 and 2 for motor and sensory conductions, respectively.

The latency of SSR achieved from the hand was $1.50 \pm$ $0.28 \mathrm{~ms}$ in the study group versus $1.46 \pm 0.13$ in the control group, $p=0.0465$. The SSR latency achieved from the foot was $2.44 \pm 0.51 \mathrm{~ms}$ and $2.13 \pm 0.21 \mathrm{~ms}, p<$ 0.0000 , respectively.

Analysis of sensation thresholds in the different modalities in the C8 and S1 skin regions revealed significant differences between study and control groups (Tables 3 and 4). Differences were seen in both C8 and S1 regions for temperature and pain thresholds, and for the vibratory threshold only in the S1 region. In the upper limb, the vibratory threshold was similar in both groups. We assessed the dispersions of low (cold) and high (warm) temperatures in the $\mathrm{C} 8$ and S1 skin regions. Statistically significant differences were seen only in the $\mathrm{C} 8$ region, but for both cold and warm sensations (Table 5, Fig. 1).

The correlations between the analyzed parameters of standard neurography, SSR, TSA and levels of heavy 
Table 1 Motor conduction parameters in the ulnar and peroneal nerves in the study and control groups

\begin{tabular}{|c|c|c|c|c|c|c|}
\hline \multicolumn{2}{|c|}{ nerve/parameter } & \multicolumn{2}{|c|}{$\begin{array}{l}\text { study group } \\
n=41\end{array}$} & \multicolumn{2}{|c|}{$\begin{array}{l}\text { control group } \\
n=36\end{array}$} & \multirow[t]{2}{*}{$\begin{array}{l}p- \\
\text { value }\end{array}$} \\
\hline & & mean & SD & mean & SD & \\
\hline \multirow[t]{4}{*}{ Ulnar } & latency (ms) & 2.7 & 0.37 & 2.6 & 0.43 & 0.0854 \\
\hline & amplitude (mV) & 9.4 & 2.09 & 9.1 & 2.28 & 0.3287 \\
\hline & conduction velocity (m/s) & 56.3 & 4.75 & 58.9 & 5.75 & 0.0375 \\
\hline & F wave (ms) & 28.2 & 1.60 & 27.2 & 1.56 & 0.0105 \\
\hline \multirow[t]{4}{*}{ peroneal } & latency (ms) & 5.0 & 1.04 & 4.5 & 0.80 & 0.0011 \\
\hline & amplitude (mV) & 5.4 & 1.77 & 8.3 & 2.88 & 0.0001 \\
\hline & conduction velocity (m/s) & 45.7 & 3.20 & 47.6 & 4.31 & 0.0379 \\
\hline & F wave (ms) & 50.1 & 3.11 & 49.1 & 1.96 & 0.0026 \\
\hline
\end{tabular}

$m s$ milliseconds, $m V$ millivolts, $\mathrm{m} / \mathrm{s}$ meters per second

metals were not generally significant. Only a few of these showed a weak relationship (maximal value 0.48 ). They did not indicate any significant regularities in relation to individual metals and did not allow us to estimate any pattern of polyneuropathy for the individual factors. When we compared sensation thresholds in the different modalities in the $C 8$ and $S 1$ skin regions in patients with $\mathrm{Cd}-\mathrm{B}, \mathrm{Pb}-\mathrm{B}, \mathrm{Zn}-\mathrm{PP}$ and As-U levels above cut-off values (Table 6), we found that the patient with high $\mathrm{Pb}-\mathrm{B}$ level had the highest thresholds of temperature and pain sensation; CP thresholds in both regions were completely undetectable. High Zn-PP values were not connected with significantly higher thresholds, which were around mean values in the study group. The results found in the patient with high levels of both $\mathrm{Cd}-\mathrm{B}$ and $\mathrm{As}-\mathrm{U}$ were higher than the average results in the study group, but not as high as those in the aforementioned patient with significantly elevated $\mathrm{Pb}-\mathrm{B}$ level. The highest vibratory thresholds, mainly in the S1 region, were seen in those patients with abnormal As-U levels. The temperature dispersions (the temperature difference between feeling pain and temperature sensation) for low and high temperatures in those patients with $\mathrm{Cd}-\mathrm{B}, \mathrm{Pb}-\mathrm{B}, \mathrm{Zn}-\mathrm{PP}$ or

Table 2 Sensory conduction parameters in the ulnar and sural nerves in the study and control groups

\begin{tabular}{|c|c|c|c|c|c|c|}
\hline \multicolumn{2}{|c|}{ nerve/parameter } & \multicolumn{2}{|c|}{$\begin{array}{l}\text { study group } \\
n=41\end{array}$} & \multicolumn{2}{|c|}{$\begin{array}{l}\text { control group } \\
n=36\end{array}$} & \multirow[t]{2}{*}{$\begin{array}{l}p \text { - } \\
\text { value }\end{array}$} \\
\hline & & mean & SD & mean & SD & \\
\hline \multirow[t]{3}{*}{ ulnar } & latency (ms) & 2.3 & 0.24 & 2.2 & 0.38 & 0.1007 \\
\hline & amplitude $(\mu \mathrm{V})$ & 20.6 & 6.88 & 25.3 & 11.51 & 0.0109 \\
\hline & conduction velocity $(\mathrm{m} / \mathrm{s})$ & 51.2 & 6.12 & 57.0 & 7.16 & 0.0005 \\
\hline \multirow[t]{3}{*}{ sural } & latency (ms) & 2.80 & 0.54 & 2.38 & 0.49 & 0.0022 \\
\hline & amplitude $(\mu \mathrm{V})$ & 9.8 & 3.92 & 14.6 & 6.13 & 0.0002 \\
\hline & conduction velocity $(\mathrm{m} / \mathrm{s})$ & 51.7 & 10.00 & 50.3 & 6.57 & 0.0666 \\
\hline
\end{tabular}

ms milliseconds, $\mu \mathrm{V}$ microvolts, $\mathrm{m} / \mathrm{s}$ meters per second
As- $U$ levels above the cut-off values were generally smaller in the lower limbs than in the upper limbs, similar to the control group.

\section{Discussion}

Exposure to heavy metals in high concentrations mainly occurs in the metal industry. Co-exposure to several heavy metals, not infrequently including other occupational factors, is highly likely in this industry. The effects on e.g. DNA, carcinogenesis, and faetal development as a result of co-exposure to toxins seem to exceed the sum of effects of single metals [16, 17, 31-33]. However, it is also possible that co-exposure to some metals (As and $\mathrm{Pb}, \mathrm{Pb}$ and $\mathrm{Cd}$ ) has antagonistic effects $[6,34]$. The influence of co-exposure to heavy metals on the peripheral nervous system is equivocal [18]. In our study group, less than $20 \%$ of volunteers had clinical symptoms of polyneuropathy. This allowed us to recognize a length-dependent pattern of polyneuropathy, mostly with dominant sensory disturbances. Standard NCS testing of motor and sensory fibers confirmed peripheral nerve damage. Changes were found in upper and lower limbs in respect of sensory, as well as motor fibers. We found the electrophysiological features of both axonal

Table 3 Mean QST parameters in C8 in the study and control groups

\begin{tabular}{|c|c|c|c|c|c|}
\hline \multirow[t]{2}{*}{$\begin{array}{l}\text { C8 region/ } \\
\text { parameter }\end{array}$} & \multicolumn{2}{|c|}{$\begin{array}{l}\text { Study group } \\
n=41\end{array}$} & \multicolumn{2}{|c|}{$\begin{array}{l}\text { Control group } \\
n=36\end{array}$} & \multirow[t]{2}{*}{$p$-value } \\
\hline & mean & SD & mean & SD & \\
\hline cold sensation $\left({ }^{\circ} \mathrm{C}\right)$ & 29.4 & 0.91 & 29.8 & 1.02 & 0.0076 \\
\hline warm sensation $\left({ }^{\circ} \mathrm{C}\right)$ & 34.7 & 0.93 & 34.2 & 0.87 & 0.0098 \\
\hline cold pain $\left({ }^{\circ} \mathrm{C}\right)$ & 17.3 & 6.44 & 23.2 & 3.41 & 0.0000 \\
\hline hot pain $\left({ }^{\circ} \mathrm{C}\right)$ & 43.2 & 4.17 & 39.6 & 2.98 & 0.0000 \\
\hline vibratory limits $(\mu)$ & 2.1 & 1.57 & 1.8 & 0.74 & 0.9911 \\
\hline
\end{tabular}

${ }^{\circ} \mathrm{C}$ degrees Celsius, $\mu$ microns 
Table 4 Mean QST parameters in S1 in the study and control groups

\begin{tabular}{lllllll}
\hline $\begin{array}{llllll}\text { S1 region/ } \\
\text { parameter }\end{array}$ & \multicolumn{2}{l}{$\begin{array}{l}\text { Study group } \\
\boldsymbol{n}=\mathbf{4 1}\end{array}$} & & \multicolumn{2}{l}{$\begin{array}{l}\text { Control group } \\
\boldsymbol{n}=\mathbf{3 6}\end{array}$} & \multirow{2}{p}{$\begin{array}{l}\boldsymbol{p} \text { - } \\
\text { value }\end{array}$} \\
\cline { 2 - 3 } & mean & SD & & Mean & SD & \\
\hline cold sensation $\left({ }^{\circ} \mathrm{C}\right)$ & 26.5 & 2.08 & 28.5 & 1.92 & 0.0001 \\
warm sensation $\left({ }^{\circ} \mathrm{C}\right)$ & 38.8 & 3.20 & 36.5 & 2.01 & 0.0011 \\
cold pain $\left({ }^{\circ} \mathrm{C}\right)$ & 18.9 & 7.24 & 21.9 & 5.01 & 0.0012 \\
hot pain $\left({ }^{\circ} \mathrm{C}\right)$ & 44.6 & 3.01 & 41.9 & 1.87 & 0.0000 \\
vibratory limits $(\mu)$ & 7.1 & 6.44 & 2.8 & 1.16 & 0.0001 \\
\hline
\end{tabular}

${ }^{\circ} \mathrm{C}$ degrees Celsius, $\mu$ microns

lesion and demyelination. Even though we did not consider the sensory latency values, motor latency and motor and sensory conduction velocities resulting from demyelination differed significantly from the control group, as did amplitude values (axonal lesion). $P$-values for most sensory parameters were much lower $(p>$ 0.001) than for motor ones, and in the peroneal nerve compared to the ulnar nerve; typically, more pronounced changes were seen within sensory fibers, and in the lower limbs.

In their longitudinal study using NCS, Ishii et al. [35] confirmed sensory impairment in upper and lower limbs with only slight motor dysfunction after arsenic intoxication. Mixed, axonal and demyelinating peripheral neuropathy could develop as a subacute damage [22, 36-40] and even be found after drinking water contaminated with a very low dose of arsenic [41]. On the other hand, in some studies only subclinical forms of arsenic polyneuropathy have been noted after occupational, longlasting exposure [42], and this usually takes the form of axonal sensory neuropathy $[37,43]$.

Cadmium is a known, potent toxin for cortical neurons, even in low doses [44]. Cadmium intoxication can lead to olfactory, neurobehavioral, and memory problems, and may underlie neurodegeneration [4, 13, 45-47]. Little is known about the influence of cadmium on the peripheral nervous system [15, 48]. The adverse effects of cadmium on the auditory system have been described in some studies [18].

Table 5 Dispersion (the temperature difference between feeling pain and temperature sensation) of low (cold) and high (warm) temperatures (in ${ }^{\circ} \mathrm{C}$ ) in the $\mathrm{C} 8$ and $\mathrm{S} 1$ skin regions

\begin{tabular}{|c|c|c|c|c|c|}
\hline \multirow[t]{2}{*}{$\begin{array}{l}\text { Skin region/ } \\
\text { parameter }\end{array}$} & \multicolumn{2}{|c|}{$\begin{array}{l}\text { study group } \\
n=41\end{array}$} & \multicolumn{2}{|c|}{$\begin{array}{l}\text { control group } \\
n=36\end{array}$} & \multirow[t]{2}{*}{$p$-value } \\
\hline & mean & SD & Mean & SD & \\
\hline C8 cold dispersion $\left({ }^{\circ} \mathrm{C}\right)$ & 11.25 & 3.47 & 7.14 & 3.10 & $<0.0001$ \\
\hline C8 warm dispersion $\left({ }^{\circ} \mathrm{C}\right)$ & 8.24 & 4.86 & 5.41 & 2.58 & 0.0015 \\
\hline S1 cold dispersion $\left({ }^{\circ} \mathrm{C}\right)$ & 6.95 & 4.91 & 6.59 & 3.76 & 0.7849 \\
\hline $\mathrm{S} 1$ warm dispersion $\left({ }^{\circ} \mathrm{C}\right)$ & 5.85 & 2.32 & 5.34 & 1.81 & 0.3153 \\
\hline
\end{tabular}

${ }^{\circ} \mathrm{C}$ degrees Celsius
Viaene et al. [15] suggested the promoting role of cadmium in the development of polyneuropathy at an older age.

Lead neuropathy has been described by many authors, with the classical predomination of muscle weakness in forearm extensors with very slight sensory involvement [7, 9, 11, 40, 43, 49]. Distal, symmetric, sensory and motor polyneuropathy occur less commonly in lead intoxication $[8,9,11]$. Classical lead neuropathy is usually subacute and develops after relatively short exposure to high lead concentrations, while chronic exposure to inorganic lead leads to mild sensory and autonomic symptoms $[7,8]$. Based on the determination of DNA single stand break (DNA-SSB) induction and repair capacity for 8oxoguanine in mononuclear blond cells, Hengstler et al. [31] proved the interactive effects of co-exposure to cadmium, cobalt and lead, and their genotoxic effects even in non-critical concentrations. In another study, Xue et al. [16] confirmed that chronic exposure to metal mixtures may increase these toxic effects, but on the other hand coexposure to specific metals, e.g. As and $\mathrm{Pb}$, may have antagonistic effects leading to a reduction of toxicity.

Little is known about the effect of co-exposure to heavy metals on the peripheral nervous system. For our study, we included workers with prolonged professional exposure to different heavy metals $-\mathrm{Pb}, \mathrm{Cd}$, As. Our neurophysiological findings confirmed peripheral nerve damage in all of them. Clinically, polyneuropathy was seen in $20 \%$, while standard neurophysiological tests in the majority of the results achieved from lower limbs were incorrect. We were able to conclude that coexposure to combinations of the above heavy metals produced more pronounced and more easily identifiable neuropathy. The additive influence of mixed heavy metals on peripheral nerves is possible, even though one of our patients with both Cd-B and As-U levels above cut-off values had elevated, but not the highest, temperature and pain thresholds. Additionally, during our evaluation of the function of small fibers of peripheral nerves, we more clearly noted abnormalities in our patients. Nearly all parameters significantly differed between groups, and the electrophysiological signs of polyneuropathy were also clearly positive in the upper limbs. All our investigations confirmed the lesion of all fiber types, large and small, in the lower limbs. Greater differences in the dispersion of low and high temperatures, which resulted from the higher thresholds of pain sensation, were found only in the $\mathrm{C} 8$ region. This was also confirmed in 7 patients with high $\mathrm{Cd}-\mathrm{B}, \mathrm{Pb}-\mathrm{B}, \mathrm{Zn}-\mathrm{PP}$ and As-U levels, which were above cut-off values. This allowed us to state that small fibers (A-delta and C) are damaged earlier than large fibers. Estimation of their function should be considered in the early diagnosis of toxic polyneuropathy or in low-dose exposure to heavy metals. Our conclusions remain consistent with those of 


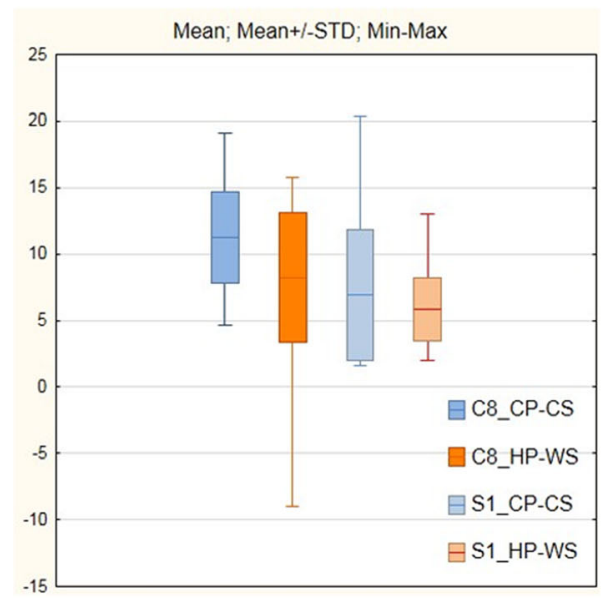

A

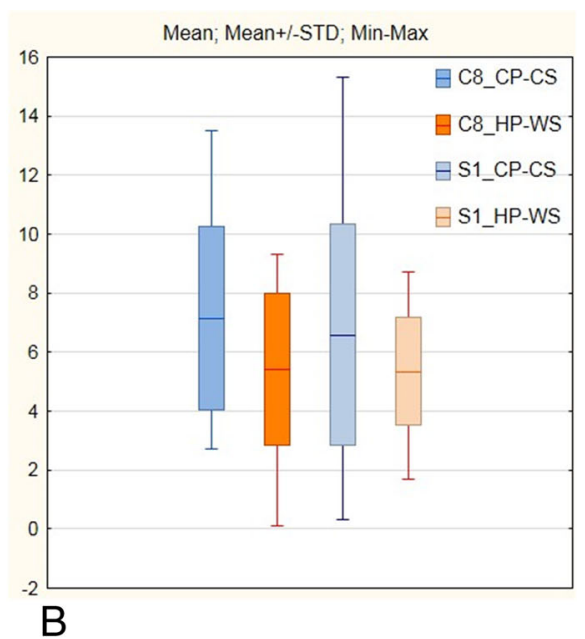

Fig. 1 Dispersion (the temperature difference between feeling pain and temperature sensation) of low (cold) and high (warm) temperatures (in $\left.{ }^{\circ} \mathrm{C}\right)$ in the C8 and S1 skin regions in metal industry workers (a) and controls (b). CS - cold sensation, WS - warm sensation, CP - cold pain, HP - heat pain many previous studies. A chronic length-dependent sensorimotor polyneuropathy, in many cases presenting as sensory-predominant painful neuropathy, is seen in the toxicity of heavy metals $[1,2,5,6,10,15,21,40,50]$. However, sensory disturbances in patients with chronic arsenic exposure seem to be related not only to peripheral neuropathy but also to impairment of the central nervous system [51]. Gobba et al. [23, 24] proved that exposure to industrial metals could affect different sensory functions: hearing, taste, etc. Marcetti [52] underlined dysfunction in smell with cadmium and nickel toxicity. Chronic exposure to arsenic in drinking water, even in low concentrations, can produce objective neuropathies in both large and small fibers [41]. Considering our two patients with high As-U values we can state more pronounced changes in vibratory thresholds, thus in large diameter sensory fibers. Predominantly, sensory polyneuropathy together with autonomic symptoms is observed in $48 \%$ of patients exposed to arsenic [53]. In chronic lowlevel lead intoxication, an impact on unmyelinated small fibers has also been proved in individual studies [54].

The limitations of our study included the small number of participants, and the lack of control groups consisting of patients exposed to single heavy metals separately. We were unable to find any significant correlation between parameters for large and small fiber dysfunction and the concentrations of the individual heavy metals. Therefore, we could not find or match any specific neurophysiological pattern to the respective heavy metals $-\mathrm{Cd}$, As, and $\mathrm{Pb}$.

Table 6 Heavy metals levels and TSA results in the study group (mean values) and in 7 patients with high levels (above cut-off value) of $\mathrm{Cd}-\mathrm{B}, \mathrm{Pb}-\mathrm{B}, \mathrm{Zn}-\mathrm{PP}$ or $\mathrm{As}-\mathrm{U}$

\begin{tabular}{|c|c|c|c|c|c|c|c|c|c|c|c|c|c|c|c|c|c|c|}
\hline & \multirow{2}{*}{$\begin{array}{l}C d-B \\
(\mu \mathrm{g} / \mathrm{l})\end{array}$} & \multirow{2}{*}{$\begin{array}{l}\text { PB-B } \\
(\mu \mathrm{g} / \mathrm{l})\end{array}$} & \multirow{2}{*}{$\begin{array}{l}\text { As-U } \\
(\mu \mathrm{g} / \mathrm{g} \\
\text { creat.) }\end{array}$} & \multirow{2}{*}{$\begin{array}{l}Z n-P P \\
(\mu \mathrm{g} / \mathrm{dl})\end{array}$} & \multicolumn{7}{|l|}{$\mathrm{C} 8$} & \multicolumn{7}{|l|}{ S1 } \\
\hline & & & & & $\begin{array}{l}\mathrm{CS} \\
\left({ }^{\circ} \mathrm{C}\right)\end{array}$ & $\begin{array}{l}\text { WS } \\
\left({ }^{\circ} \mathrm{C}\right)\end{array}$ & $\begin{array}{l}\mathrm{CP} \\
\left({ }^{\circ} \mathrm{C}\right)\end{array}$ & $\begin{array}{l}\mathrm{HP} \\
\left({ }^{\circ} \mathrm{C}\right)\end{array}$ & $\begin{array}{l}\text { VS } \\
(\mu)\end{array}$ & CS-CP & HP-WS & $\begin{array}{l}\mathrm{CS} \\
\left({ }^{\circ} \mathrm{C}\right)\end{array}$ & $\begin{array}{l}\text { WS } \\
\left({ }^{\circ} \mathrm{C}\right)\end{array}$ & $\begin{array}{l}\mathrm{CP} \\
\left({ }^{\circ} \mathrm{C}\right)\end{array}$ & $\begin{array}{l}\text { HP } \\
\left({ }^{\circ} \mathrm{C}\right)\end{array}$ & $\begin{array}{l}\text { VS } \\
(\mu)\end{array}$ & CS-CP & HP-WS \\
\hline study group & 1.19 & 181.85 & 15.60 & 18.35 & 29.4 & 34.7 & 17.3 & 43.2 & 2.1 & 11.3 & 8.24 & 26.5 & 38.8 & 18.9 & 44.6 & 7.1 & 6.9 & 5.9 \\
\hline Patient 1 & 7.17 & 374 & 88 & 50 & 30.3 & 34.8 & 19.7 & 49.5 & 1.1 & 10.6 & 14.7 & 29.6 & 41.7 & 21 & 46.6 & 1.9 & 8.6 & 4.9 \\
\hline Patient 2 & 0.42 & 211 & 42.1 & 8 & 28.8 & 35.1 & 19.6 & 46.9 & 1.5 & 9.2 & 11.8 & 26.5 & 40.5 & 23.1 & 44.9 & 2.6 & 3.4 & 4.4 \\
\hline Patient 3 & 1.74 & 322 & 44.8 & 11 & 30.2 & 33.6 & 21.5 & 41.7 & 1.1 & 8.7 & 8.1 & 26.4 & 36.3 & 24.1 & 42.1 & 5.1 & 2.3 & 5.8 \\
\hline Patient 4 & 0.21 & 610 & 3.84 & 9 & 29.5 & 36.2 & a & 49.6 & 1.9 & b & 13.4 & 27.5 & 44.8 & a & 49.8 & 1.2 & b & 5.0 \\
\hline Patient 5 & 0.43 & 409 & 45.8 & 4 & 29.7 & 33.5 & 12.9 & 44.5 & 2.4 & 16.8 & 10.0 & 23.1 & 43.5 & 21.1 & 47.4 & 10.9 & 2.0 & 3.9 \\
\hline Patient 6 & 0.29 & 384 & 22.1 & 88 & 30.4 & 34.9 & 15.3 & 45.7 & 1.2 & 15.1 & 10.8 & 29.9 & 42.8 & 19.8 & 48.6 & 8.4 & 10.1 & 5.8 \\
\hline Patient 7 & 0.48 & 66.7 & 3.9 & 106 & 28.8 & 34.1 & 20.7 & 43.9 & 0.7 & 8.1 & 9.8 & 27.8 & 34.9 & 22.1 & 42.6 & 1.6 & 5.7 & 7.7 \\
\hline
\end{tabular}

andetectable

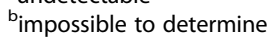




\section{Conclusions}

We can conclude that co-exposure to many heavy metals results in explicit impairment of peripheral nerves, which is more pronounced within small fibers. We can state that the most interesting finding was the dispersion of low and high temperatures, which was predominantly connected with greater impairment of temperature-dependent pain thresholds. We confirmed that QST is a sensitive test, and allows the demonstration, with a high degree of sensitivity, of even slight impairment to small fibers in toxic neuropathy. The evaluation of small fiber function should be considered in the early diagnosis of toxic polyneuropathy or in lowdose exposure to heavy metals. Our results did not allow us to assign our neurophysiological findings to the influence of a particular heavy metal or its level. Based on the literature review, we can state that few studies have been conducted into small fiber neuropathy due to heavy metal intoxication, so our study seems to be an important, additional element in the field of the medicine of industrial toxicology.

\section{Abbreviations}

$\mu / \mathrm{s}$ : Microns per second; $\mu \mathrm{V}$ : Microvolts; As: Arsenic; As-U: Urine levels of arsenic; BMl: Body mass index; Cd: Cadmium; Cd-B: Blood levels of cadmium; CP: Cold pain; CS: Cold sensation; DNA-SSB: DNA single stand break; HP: Heat pain; m/s: Meters per second; MMP Plus: Multi-Mode Program; ms: Milliseconds; mV: Millivolts; NCS: Nerve conduction study; Pb: Lead; PbB: Blood levels of lead; QST: Quantitative sensation testing; TSA II: Thermal Sensory Analyzer II; VS: Vibratory sensation; WS: Warm sensation; ZnPP: Blood levels of zinc protoporphyrin

\section{Acknowledgements}

There are no acknowledgments.

\begin{abstract}
Authors' contributions
MK - made substantial contributions to the conception and design of the work, corresponding author; KM, MW-P - made substantial contributions in acquisition and analysis of the neurophysiological data; RP, PC, AS-C - made substantial contributions in the acquisition and analysis of the occupational, and toxicological data; ME, KS - drafted the work; MW - conducted the statistical analysis; GM, SB - revised the manuscript. The author (s) read and approved the final manuscript.
\end{abstract}

\section{Funding}

Supported by Wroclaw Medical University, Poland, number: SUB.C220.21.028.

\section{Availability of data and materials}

The datasets used and analyzed during the current study are available from the corresponding author on reasonable request.

\section{Declarations}

\section{Ethics approval and consent to participate}

The Ethics Committee of Wroclaw Medical University in Poland, approval number KB-357/2010.

\section{Consent for publication}

The authors received consent forms from all volunteers who took part in the study, and have them on file in case they are requested by the editor.

\section{Competing interests}

The authors declare that they have no competing interests.

\section{Author details}

'Department of Neurology, Wroclaw Medical University, Borowska 213, 50-556 Wroclaw, Poland. 'Department of Internal Medicine, Occupational Diseases, Hypertension and Clinical Oncology, Wroclaw Medical University, Borowska 213, 50-550 Wroclaw, Poland. ${ }^{3}$ Department of Hygiene, Wroclaw Medical University, J. Mikulicza-Radeckiego 7, 50-345 Wroclaw, Poland.

${ }^{4}$ Faculty of Earth Sciences and Environmental Management, University of Wroclaw, Plac Uniwersytecki 1, 50-137 Wroclaw, Poland.

Received: 25 December 2020 Accepted: 3 April 2021

Published online: 15 April 2021

\section{References}

1. Watson JC, Dyck PJ. Peripheral neuropathy: a practical approach to diagnosis and symptom management. Mayo Clin Proc. 20151;90(7):940-51. https://doi.org/10.1016/j.mayocp.2015.05.004.

2. Li Y. Axonal Sensorimotor Polyneuropathies. Continuum (Minneap Minn). 2017;23(5, Peripheral Nerve and Motor Neuron Disorders):1378-93.

3. Gerr F, Letz R. Epidemiological case definitions of peripheral neuropathy: experience from two neurotoxicity studies. Neurotoxicology. 2000;21(5):761-8.

4. Sankhla MS. Sharma K, Kumar R. heavy metal causing neurotoxicity in human health. International journal of innovative research in science. Eng Technol. 2017;6(5):7721-6.

5. Gaioli GM, González DE, Areny G, Grela M, Amoedo D. Heavy metals in the enviroment: Guillain-Barre like syndrome. Arch Argent Pediatr. 2020;118(1): e48-52. https://doi.org/10.5546/aap.2020.e48.

6. Sińczuk-Walczak H. Zmiany w układzie nerwowym w nastipstwie narazenia zawodowego na arsen i zwiizki nieorganiczne arsenu w swietle piśmiennictwa [nervous system disorders induced by occupational exposure to arsenic and its inorganic compounds: a literature review]. Med Pr. 2009; 60(6):519-22 Polish

7. Rubens O, Logina I, Kravale I, Eglite M, Donaghy M. Peripheral neuropathy in chronic occupational inorganic lead exposure: a clinical and electrophysiological study. J Neurol Neurosurg Psychiatry. 2001;71(2):200-4. https://doi.org/10.1136/jnnp.71.2.200.

8. Thomson RM, Parry GJ. Neuropathies associated with excessive exposure to lead. Muscle Nerve. 2006;33(6):732-41. https://doi.org/10.1002/mus.20510.

9. Krieg EF Jr, Chrislip DW, Brightwell WS. A meta-analysis of studies investigating the effects of lead exposure on nerve conduction. Arch Toxicol. 2008;82(8):531-42. https://doi.org/10.1007/s00204-008-0292-z.

10. Blisard KS. Heavy metal neuropathies. In: Fenoglio-Preiser CM, Wolff M, Rilke F, editors. Progress in surgical pathology. Berlin, Heidelberg: Springer; 1989. https://doi.org/10.1007/978-3-662-12814-5_5.

11. Sadeghniiat-Haghighi K, Saraie M, Ghasemi M, Izadi N, Chavoshi F, Khajehmehrizi A. Assessment of peripheral neuropathy in male hospitalized patients with lead toxicity in Iran. J Res Med Sci. 2013;18(1):6-9.

12. Ağar A, Yargiçoğlu P, Edremitlioğlu M, Kara C, Oğuz Y. The effect of cadmium (cd) treatment on somatosensory evoked potentials (SEPS) and conduction velocity in alloxane-induced diabetic rats: relation to lipid peroxidation. J Basic Clin Physiol Pharmacol. 1999;10(1):41-56. https://doi. org/10.1515/jbcpp.1999.10.1.41.

13. Viaene MK, Masschelein R, Leenders J, de Groof M, Swerts $L$, Roels HA. Neurobehavioural effects of occupational exposure to cadmium: a cross sectional epidemiological study. Occup Environ Med. 2000;57(1):19-27. https://doi.org/10.1136/oem.57.1.19.

14. Minami A, Takeda A, Nishibaba D, Takefuta S, Oka N. Cadmium toxicity in synaptic neurotransmission in the brain. Brain Res. 2001;894(2):336-9. https://doi.org/10.1016/S0006-8993(01)02022-4.

15. Viaene MK, Roels HA, Leenders J, de Groof M, Swerts LJ, Lison D, et al, Cadmium: a possible etiological factor in peripheral polyneuropathy. Neurotoxicology. 1999;20(1):7-16.

16. Xue S, Shi L, Wu C, Wu H, Qin Y, Pan W, et al. Cadmium, lead, and arsenic contamination in paddy soils of a mining area and their exposure effects on human HEPG2 and keratinocyte cell-lines. Environ Res. 2017;156:23-30. https://doi.org/10.1016/j.envres.2017.03.014.

17. Bellés $M$, Albina $M$, Sánchez $D$, Corbella J, Domingo JL. Interactions in developmental toxicology: effects of concurrent exposure to Lead, organic mercury, and arsenic in pregnant mice. Arch Environ Contam Toxicol. 2002; 42(1):93-8. https://doi.org/10.1007/s002440010296.

18. Castellanos M-J. Fuente A. The adverse effects of heavy metals with and without noise exposure on the human peripheral and central auditory 
system: a literature review. Int J Environ Res Public Health. 2016;13(12):1223. https://doi.org/10.3390/ijerph13121223.

19. Oh SJ. Clinical electromyography: nerve conduction studies. Philadelphia: Lippincott, Williams and Wilkins; 2003.

20. Mallik A, Weir Al. Nerve conduction studies: Essentials and pitfalls in practice. J Neurol Neurosurg Psychiatry. 2005;76(suppl ii):ii23-31.

21. Toledano M. Toxin-induced neuropathies. Neurol Clin. 2020;38(4):749-63. https://doi.org/10.1016/j.ncl.2020.06.002.

22. Valappil AV, Mammen A. Subacute arsenic neuropathy: clinical and electrophysiological observations. J Neurosci Rural Pract. 2019;10(3):529-32. https://doi.org/10.1055/s-0039-1695693.

23. Gobba F. Sensory perception: an overlooked target of occupational exposure to metals. Bioinorg Chem Appl. 2003;1(2):199-214. https://doi. org/10.1155/S1565363303000165.

24. Gobba F. Occupational exposure to chemicals and sensory organs: a neglected research field. Neurotoxicology. 2003;24(4-5):675-91. https://doi. org/10.1016/S0161-813X(03)00038-X.

25. England JD, Gronseth GS, Franklin G, et al. American Academy of Neurology. Practice Parameter: evaluation of distal symmetric polyneuropathy: role of autonomic testing, nerve biopsy, and skin biopsy (an evidence-based review). Report of the American Academy of Neurology, American Association of Neuromuscular and Electrodiagnostic Medicine, and American Academy of Physical Medicine and Rehabilitation. Neurology. 2009;72(2):177-84

26. Siao P, Cros DP. Quantitative sensory testing. Phys Med Rehabil Clin N Am. 2003;14(2):261-86. https://doi.org/10.1016/S1047-9651(02)00122-5.

27. Report of the therapeutics and technology assessment Subcommittee of the American Academy of neurology assessment: clinical autonomic testing. Neurology. 1996;46(3):873-80.

28. Kucera P, Goldenberg Z, Kurca E. Sympathetic skin response: review of the method and its clinical use. Bratisl Lek Listy. 2004;105(3):108-16.

29. Shy ME, Frohman EM, So YT, Arezzo JC, Cornblath DR, Giuliani MJ, et al. Quantitative sensory testing. Report of the therapeutics and technology assessment Subcommittee of the American Academy of neurology. Neurology. 2003;60(6):898-904. https://doi.org/10.1212/01.WNL.0000058546.16985.11.

30. Nebuchennykh M, Løseth S, Stålberg E, Mellgren SI. Quantitative sensory testing in patients with polyneuropathy and healthy individuals. Acta Neurol Scand Suppl. 2008;188:56-61. https://doi.org/10.1111/j.1600-0404.2008.01033.x.

31. Hengstler JG, Bolm-Audorff U, Faldum A, Janssen K, Reifenrath M, Götte W, et al. Occupational exposure to heavy metals: DNA damage induction and DNA repair inhibition prove co-exposures to cadmium, cobalt and lead as more dangerous than hitherto expected. Carcinogenesis. 2003;24(1):63-73. https://doi.org/10.1093/carcin/24.1.63.

32. Zhou F, Xie J, Zhang S, et al. Lead, cadmium, arsenic, and mercury combined exposure disrupted synaptic homeostasis through activating the Snk-SPAR pathway. Ecotoxicol Environ Saf. 2018;163:674-84.

33. Bertin M, Nguyen TH, Bonvallot N, Bodin J, Roquelaure Y. Occupational coexposure to biomechanical factors and neurotoxic chemicals in a representative sample of French employees. J Occup Health. 2020;62(1): e12090. https://doi.org/10.1002/1348-9585.12090.

34. Antonio Garcia T, Corredor L. Biochemical changes in the kidneys after perinatal intoxication with lead and/or cadmium and their antagonistic effects when coadministered. Ecotoxicol Environ Saf. 2004:57(2):184-9. https://doi.org/10.1016/S0147-6513(03)00063-0.

35. Ishii N, Mochizuki H, Ebihara Y, Shiomi K, Nakazato M. Clinical symptoms, neurological signs, and electrophysiological findings in surviving residents with probable arsenic exposure in Toroku. Japan Arch Environ Contam Toxicol. 2018;75(4):521-9. https://doi.org/10.1007/s00244-018-0544-8.

36. Murphy MJ, Lyon LW, Taylor JW. Subacute arsenic neuropathy: clinical and electrophysiological observations. J Neurol Neurosurg Psychiatry. 1981; 44(10):896-900. https://doi.org/10.1136/jnnp.44.10.896.

37. Halatek T, Sinczuk-Walczak H, Rabieh S, Wasowicz W. Association between occupational exposure to arsenic and neurological, respiratory and renal effects. Toxicol Appl Pharmacol. 2009;239(2):193-9. https://doi.org/10.1016/j. taap.2009.04.022

38. Sharma A, Kumar S. Arsenic exposure with reference to neurological impairment: an overview. Rev Environ Health. 2019;34(4):403-14. https://doi. org/10.1515/reveh-2019-0052

39. Jomova K, Jenisova Z, Feszterova M, Baros S, Liska J, Hudecova D, et al. Arsenic: toxicity, oxidative stress and human disease. J Appl Toxicol. 2011; 31(2):95-107. https://doi.org/10.1002/jat.1649.
40. Misra UK, Kalita J. Toxic neuropathies. Neurol India. 2009;57(6):697-705. https://doi.org/10.4103/0028-3886.59463.

41. Mochizuki H, Phyu KP, Aung MN, Zin PW, Yano Y, Myint MZ, et al. Peripheral neuropathy induced by drinking water contaminated with low-dose arsenic in Myanmar. Environ Health Prev Med. 2019;24(1):23. https://doi.org/10.11 86/s12199-019-0781-0.

42. Blom S, Lagerkvist B, Linderholm H. Arsenic exposure to smelter workers. Clinical and neurophysiological studies. Scand J Work Environ Health. 1985 Aug;11(4):265-9. https://doi.org/10.5271/sjweh.2227.

43. Staff NP, Windebank AJ. Peripheral neuropathy due to vitamin deficiency, toxins, and medications. Continuum (Minneap Minn). 2014;20(5 Peripheral Nervous System Disorders):1293-306.

44. Rafati Rahimzadeh M, Rafati Rahimzadeh M, Kazemi S, Moghadamnia AA. Cadmium toxicity and treatment: an update. Caspian J Intern Med. 2017; 8(3):135-45. https://doi.org/10.22088/cjim.8.3.135.

45. Branca JJV, Morucci G, Pacini A. Cadmium-induced neurotoxicity: still much ado. Neural Regen Res. 2018;13(11):1879-82. https://doi.org/10.4103/1673-53 74.239434.

46. Wang B, Du Y. Cadmium and its neurotoxic effects. Oxidative Med Cell Longev. 2013;2013:898034.

47. Rehman K, Fatima F, Waheed I, Akash MSH. Prevalence of exposure of heavy metals and their impact on health consequences. J Cell Biochem. 2018;119(1):157-84. https://doi.org/10.1002/jcb.26234.

48. Yu CG, Wei FF, Yang WY, Zhang ZY, Mujaj B, Thijs L, et al. Heart rate variability and peripheral nerve conduction velocity in relation to blood lead in newly hired lead workers. Occup Environ Med. 2019;76(6):382-8. https://doi.org/10.1136/oemed-2018-105379.

49. Manji H. Toxic neuropathy. Curr Opin Neurol. 2011;24(5):484-90. https://doi. org/10.1097/WCO.0b013e32834a94b6

50. Mochizuki H, Yagi K, Tsuruta K, Taniguchi A, Ishii N, Shiomi K, et al. Prolonged central sensory conduction time in patients with chronic arsenic exposure. J Neurol Sci. 2016;361:39-42. https://doi.org/10.1016/j.jns.2015.12.020.

51. Marchetti C. Interaction of metal ions with neurotransmitter receptors and potential role in neurodiseases. Biometals. 2014;27(6):1097-113. https://doi. org/10.1007/s10534-014-9791-y.

52. Chakraborti D, Rahman MM, Ahamed S, Dutta RN, Pati S, Mukherjee SC. Arsenic contamination of groundwater and its induced health effects in Shahpur block, Bhojpur district, Bihar state, India: risk evaluation. Environ Sci Pollut Res Int. 2016;23(10):9492-504. https:/doi.org/10.1007/s11356-016-6149-8.

53. Nora DB, Gomes I, Said G, Carvalho FM, Melo A. Modifications of the sympathetic skin response in workers chronically exposed to lead. Braz J Med Biol Res. 2007;40(1):81-7. https://doi.org/10.1590/S0100-879X2007000100011.

54. López E, Figueroa S, Oset-Gasque MJ, González MP. Apoptosis and necrosis: two distinct events induced by cadmium in cortical neurons in culture. $\mathrm{Br}$ J Pharmacol. 2003;138(5):901-11. https://doi.org/10.1038/sj.bjp.0705111.

\section{Publisher's Note}

Springer Nature remains neutral with regard to jurisdictional claims in published maps and institutional affiliations.

\section{Ready to submit your research? Choose BMC and benefit from:}

- fast, convenient online submission

- thorough peer review by experienced researchers in your field

- rapid publication on acceptance

- support for research data, including large and complex data types

- gold Open Access which fosters wider collaboration and increased citations

- maximum visibility for your research: over $100 \mathrm{M}$ website views per year

At $\mathrm{BMC}$, research is always in progress.

Learn more biomedcentral.com/submission 